\section{Holland and the War}

THIS aspect is obviously of interest in relation to the question of European order on which Prof. G. N. Clark's pamphlet (No. 49, "Holland and the War") has an important bearing. Prof. Clark gives a picture of the economic position of Holland, her social structure and her constitution, and against this background describes her foreign policy in recent years and the circumstances under which she entered the War with her powerful material resources in the East Indies. He describes briefly the effects of the German occupation and Holland's aims in the Wara just and stable international order-and emphasizes the value of the freedom of the Netherlands to the civilization of the world. The preservation of that freedom, when restored, depends on the collective strength and wisdom of the friends of justice.

\section{Carnegie United Kingdom Trust}

THe twenty-seventh annual report of the Carnegie United Kingdom Trust (Dunfermline: The Trust) covers the year 1940 and emphasizes the aim of its war-time policy to continue so far as possible to foster pioneer experimental work which may be expected to have an enduring effect on the social structure of the country. It also aims at safeguarding its own past work where this has proved to be of value by assisting earlier beneficiaries to maintain their services and, if necessary, extend them to meet special needs arising from the War. The year 1940 was the last year of a quinquennium, and the report briefly reviews the allocations made during that period. The largest single allocation was one of a $£ 150,000$ for land settlement schemes to be undertaken in England and Wales by the Land Settlement Association. The policy of this Association had to be completely re-orientated at the outbreak of war. At September 30, 1940, there were 1,054 holders on fulltime estates, and the land has been brought under cultivation for production of corn, potatoes and other crops under schemes agreed with the county war agricultural committees. Individual grants to the National Council of Social Service have been rounded into a single block grant of $£ 5,000$ for 1940 to cover all those of the Council's activities in which the Trust is interested.

In the field of adult education, the main allocations during the period have been for the adaptation and equipment of Lord Lothian's gift of New Battle Abbey as a residential college for adult education and for two special inquiries into the problems of young people between the ages of eighteen and twenty-five. The preliminary area reports in the Age Group Enquiry reached an advanced stage of completion by the autumn of 1939 , and the report covering the Cardiff district is being published independently under the auspices of the South Wales Council of Social Service and the Welsh University Press Board. The continued development of the Regional Library Bureaux presents the most interesting feature of library history of the last five years, and reference is made in the report to the assistance given to these Bureaux as well as to the National Central Library. Bulk allocations approved for 1941 include $£ 8,000$ to central libraries, $£ 5,000$ to the National Council of Social Service, $£ 20,000$ for youth services and $£ 3,500$ for land settlements. An immediate grant of $£ 2,700$ has been promised to the National Council of Girls Clubs to establish a bursary fund for training potential youth leaders and the salaries and expenses of supervisors of training. A grant of $£ 2,000$ for experiments in Oxfordshire on the establishment of a number of youth service camps has also been promised.

\section{Acoustics of Argentine Chamber of Deputies}

A DEscription is given by S. D. Wilburn and S. C. Tenac in Electrical Communication (19, No. 3 ; 1941) of the system of microphones and loud-speakers designed by the Union Telefonica for the Argentine Chamber of Deputies in Buenos Aires and installed late in 1939. Investigation showed that the pronounced acoustical difficulties of the Chamber were due solely to the absence of reverberation. Structural alterations were not feasible and a system including a microphone for each individual had to be devised. The new system was first used officially at the opening session in 1940, and has given great satisfaction. It comprises 193 microphones and four loud-speakers in the Chamber. It has two independent channels of transmission : one with five microphones consisting of one each for the president of the Chamber of Deputies and the two secretaries and two on the ministers' table; the other channel is equipped for 188 individual-microphones for the deputies. The Chamber is completely surrounded by two walls with three-metre corridors between them at various heights. The four loud-speakers are located in the first gallery. A simple schematic circuit diagram of the transmission, switching and power circuits is given. The electric power consumption of the system is only $1 \cdot 1$ kilowatts.

\section{Sylviculture of some Tropical Trees}

To the forester versed in tropical forestry and who has had the opportunity of discussing sylvicultural problems with the mixed gathering found. at an international forestry congress, perhaps the most interesting section in the Malayan Forester (January, 1941) is that in which observations are made on the sylvicultural characteristics of some of the important timber species. The coppicing powers of dipterocarp regeneration show that Dryobalanops oblongifolia, Dipterocarpus Kerrii and the balan and the white meranti groups of Shorea coppice fairly freely, while the red merantis and merawan (Hopea spp.) do not: There appears also to be some indication that ability to coppice and hardiness go together ; for example, Shorea ovalis is one of the few red merantis to show some ability to coppice, whilst it has also shown itself more tolerant of transplanting than most of its group. How valuable are such practical notes is known only to those tropical foresters scattered about in India, Africa and elsewhere, who are dealing with similar problems with 